\title{
The Use of Android Comics Based on Local Potentials of Embung Tambakboyo to Improve Students' Critical Thinking Ability
}

\author{
Agustina Nur Fauziah $^{1 *}$, Heru Kuswanto ${ }^{2}$ \\ ${ }^{1}$ Science Education, Universitas Negeri Yogyakarta, Indonesia \\ ${ }^{2}$ Physics Education, Universitas Negeri Yogyakarta, Indonesia \\ ${ }^{*}$ Corresponding author. Email: agustina0013pasca.2018@student.uny.ac.id
}

\begin{abstract}
This research aims to find out the improvements in junior high school students' critical thinking ability through Android comics. This research conducted was quantitative research using non-equivalent control group design. The number of samples involved were 68 junior high school students selected by purposive sampling and grouped into experiment and control class. The media used is Android comics based on local potentials of Embung Tambakboyo that contains material of interactions living creatures with its environment. Students' critical thinking ability are analyzed based on pretest and posttest results. The N-Gain results obtained by the experiment class and control class showed the increased value for each class in the high and middle categories. Thus, it can be concluded that Android comics based on local potentials of Embung Tambakboyo that was developed could improve the critical thinking ability in science learning better than the learning media that is commonly used in schools.
\end{abstract}

Keywords: Android Comic, Critical Thinking, Junior High School, Local Potentials.

\section{INTRODUCTION}

The Industrial Revolution 4.0 has transformed the world of education to prepare who are better prepared for the future life [1]. Furthermore, the education of 4.0 harmonizes humans with technology to be able to adapt to new possibilities [2]. The assumption that technologyrelated learning environments can give students the opportunity to search and analyze information, solve problems, communicate, and collaborate, becomes the basis of technological contributions in education that can certainly meet the competencies to be able to compete in this era [3]. Education here is expected to equip the students with various abilities and to develop the cognitive capacities of the students as a systemic ability, higher order mental skills, and the ability of critical thinking [4]. Critical thinking will help students to understand the information conveyed in learning [5]. Therefore, critical thinking ability is an important ability that needs to develop by students [6], [7], because it is also necessary to understand more about natural science.

Natural science is an important part of scientific knowledge [8]. Natural science learning emphasizes the immediate experience that developing students' competencies to understand the environment through the discovery process that will make it easier for them to gain a deeper understanding [9]. Learning by leveraging the potential in the community is one way to bring direct (contextual) experience for students to make it easier to understand learning materials. This is in accordance with the statement of UURI Number 20 Years 2003 about Sistem Pendidikan Nasional in which science learning can be integrated with local potentials in the community so that the learning process of learners can be more contextual [10]. This integration can also make a good influence on the success of delivering learning content [11]. Teachers usually use common learning media such as textbooks, learning videos, or powerpoints created by teachers for the delivery of learning materials. Learning media has indeed varied, but now it is considered less to attract students in the learning process, so it requires a more innovative learning media [12]. Empirically, students tend to like picture books, filled with colour, and visualized in realistic or cartoonish forms, such as comics because in comics, the creator transmits expressions through settings and alignment of either picture only or words and images to build the narrative [13]. Comics are 
also effective in conveying natural science information over more traditional textbooks [14].

Nowadays, comics are made not only as entertainment media but can be used in education to teach science [14], [15]. When used as a way to present scientific information, comics will turn the information that is usually stiff into illustrations and events that are familiar with the imagination of children [16]. The use of comics that have colourful illustrations with short storylines will attract students [17]. Comics is one of the fun ways to teach science [18] and will help students learn more and understand science materials because it visualizes complicated things to be simpler. Learning by using comics makes students develop their thinking ability because it can make them think more actively [16]. The rapid technological advancement allows the creation of interactive learning media using smartphones as a media that can support learning [19]. Comics can also pack with the current technology on the Android base on smartphones, and is known as the Android comics [20].

Android comics can be realized into the form of an Android application with an extension (.apk) or Android Application Package. Comics that have been packaged in the form of Android apps can make it easier for students to learn because they can be used anytime and anywhere. It can also minimize the use of paper, and can have many features, such as animations/videos, online tests/quizzes, and of course the learning materials [21]. Digital comics/Android comics has benefits in developing critical thinking and critical appraisal [22]. Android comics integrated with the local potentials of Embung Tambakboyo can create a more contextual and interesting learning environment because the appearance is very familiar with student's daily life.

The critical thinking ability will easily improve if the media is interesting and can keep students motivated to learn. The use of Android comics based on local potentials of Embung Tambakboyo is expected to improve students' critical thinking ability on the material of interactions living creatures with its environment. This research was carried out to answer the question of how the improvement critical thinking ability of junior high school students after learning using Android comics based on local potentials on the material of interactions living creatures with its environment.

\section{RESEARCH METHOD}

This research is a quantitative research using nonequivalent control group design. This research was conducted in February 2020. The number of samples involved were 68 7th grade students at SMP Negeri 2 Depok selected by purposive sampling and grouped into experiment and control class.
The media used to teach experiment class is Android comics based on the local potentials of Embung Tambakboyo, while the media used to teach the control class is conventional powerpoint media that is commonly used by teachers in schools. Android comics that have been created and used have been tested by media and material experts. The comic contains material about the interaction of living things with their environment in everyday life where the storyline and setting are based on the local potential of Embung Tambakboyo, and critical thinking indicators that have been adapted to the needs of junior high school students. This comic consists of comic stories according to learning materials, videos, colour images that have been designed in such a way that they can practice students' critical thinking ability. Comic are created in the form of an Android app so students can easily access comics whenever and wherever they use their smartphones.

Early analysis of students was conducted before learning by giving pretest at the beginning of learning. Pretest consists of 4 essay question items of critical thinking abilities that have been developed by researchers. Android comics are applied during learning with discussion activities. There are 9 discussion groups consisting of four students in the experiment class. Teachers provide instruction and apperception to students, as well as provide worksheets for each group before starting core learning activities. Then to focus the students on the comics, students are welcome to open the comics and start reading the comics according to the learning objectives that have been delivered. Comics containing plots and stories based on local potentials of Embung Tambakboyo and critical thinking ability indicators used in core learning activities as material for filling out questions on student worksheets. Then, there are presentation activities and class discussions that are the climax stages of learning to train students' critical thinking ability. Critical thinking ability after learning is analyzed through posttest. The posttest question used is the same question as the pretest. The indicator of critical thinking ability can be seen in table 1 .

Android comic influences analyzed by calculating ngain to see improved students' critical thinking abilities by using Equations (1). Here is the $\mathrm{N}$-gain equation according to Hake [23]:

$\mathrm{g}=\frac{(\text { post })-(\text { pre })}{100-(\text { pre })}$

Where g or N-gain is an increase, (post) is the posttest value, (pre) is the pretest value and 100 is the ideal/maximum value. $\mathrm{N}-$ Gain values are then classified as follows if $\mathrm{g}>0.70$ then the result is in the high category, if $0.70>\mathrm{g} \geqslant 0.30$ then is in the middle category, and if $g \leqslant 0.30$ then in the low category. 
Table 1. Indicators of critical thinking ability

\begin{tabular}{|l|l|l|}
\hline \multicolumn{1}{|c|}{ Indicators } & \multicolumn{1}{|c|}{ Question Indicators } & \multicolumn{1}{c|}{ Activity } \\
\hline $\begin{array}{l}\text { Analyze Facts/ } \\
\text { Problems }\end{array}$ & $\begin{array}{l}\text { Students are able to analyze facts based on } \\
\text { the phenomenon of interaction in the form of } \\
\text { webs and food chains in an environment }\end{array}$ & $\begin{array}{l}\text { Students can analyse eating events and be } \\
\text { eaten in food chains, food webs, and food } \\
\text { pyramids found on Android comics }\end{array}$ \\
\hline Identify Problems & $\begin{array}{l}\text { Students are able to identify a problem } \\
\text { regarding symbiotic phenomena and } \\
\text { changing patterns of ecosystem that occur in } \\
\text { an environment }\end{array}$ & $\begin{array}{l}\text { Students identify symbiotic phenomena and } \\
\text { changing patterns of ecosystem based on } \\
\text { the images presented in Android comics }\end{array}$ \\
\hline $\begin{array}{l}\text { Clarify/ Evaluate } \\
\text { Logical Ideas }\end{array}$ & $\begin{array}{l}\text { Students are able to clarify concepts about } \\
\text { food chain problems and changing patterns } \\
\text { of ecosystem and provide logical ideas about } \\
\text { that }\end{array}$ & $\begin{array}{l}\text { Students give arguments about food chain } \\
\text { problems and changing patterns of } \\
\text { ecosystem and provide logical ideas about } \\
\text { that and compare with the arguments that } \\
\text { have been discussed by the other groups }\end{array}$ \\
\hline Make Conclusions & $\begin{array}{l}\text { Students are able to make conclusions } \\
\text { based on the phenomenon of changing } \\
\text { patterns of ecosystem presented }\end{array}$ & $\begin{array}{l}\text { Students can conclude learning that has } \\
\text { been done }\end{array}$ \\
\hline
\end{tabular}

\section{RESULT AND DISCUSSION}

The results include improving critical thinking ability in learning by using Android comics apps based on local potentials of Embung Tambakboyo and conventional learning media. The comics used have a background and storylines that are made according to local potentials of Embung Tambakboyo and indicators of critical thinking ability. While conventional learning media is a powerpoint that is commonly used by teachers when teaching material of interactions living creatures with its environment. The instruments for measuring the critical thinking ability are compiled based on selected critical thinking ability indicators. Teachers act as facilitators and students become the centre of learning in the learning process. This will help students to exercise their thinking ability independently [12]. Furthermore, the application of critical thinking ability in comic storylines associated with learning materials and explanations can be seen in Figure 1.

Increased students' critical thinking ability are measure using the gain test. $\mathrm{N}$-gain categorizing include that are above 0.00 and less than 0.30 with low category, $\mathrm{N}$-gain is more than equal to 0.30 and less than 0.70 with middle category, and $\mathrm{N}$-gain with value greater or equal to 0.70 with high category. The categorization results are used to determine the improvement of students' critical thinking ability in material of interactions living creatures with its environment using Android comics based on local potentials of Embung Tambakboyo and conventional learning media. Data results increased students' critical thinking ability in experiment and control class can be seen in table 2 .
Table 2. Percentage gain score in experiment class and control class.

\begin{tabular}{|l|c|c|}
\hline \multirow{2}{*}{ Gain categories } & \multicolumn{2}{|c|}{ Class } \\
\cline { 2 - 3 } & Experiment (\%) & Control (\%) \\
\hline Low & 0,00 & 3,13 \\
\hline Middle & 30,56 & 56,25 \\
\hline High & 69,44 & 40,63 \\
\hline
\end{tabular}

Table 2 shows the percentage of result N-gain in both classes categorized into three categories: low, middle, and high categories. The percentage gain score in low category is $0,00 \%$ in experiment class and $3,13 \%$ in control class. The percentage gain score in the middle category is $30,56 \%$ in experiment class and $56,25 \%$ in control class. The percentage of gain scores in the high category in experiment class is $69,44 \%$ and $40,63 \%$ in control class. Based on the results of each $\mathrm{N}$-gain score, increased critical thinking ability of students who have learned by using Android comics is better than conventional media. Furthermore, it can be seen through the pretests and posttest results of both classes in table 3 .

Table 3. Data analysis of critical thinking ability assessment result.

\begin{tabular}{|l|c|c|c|c|}
\hline \multirow{2}{*}{} & \multicolumn{2}{|c|}{ Experiment } & \multicolumn{2}{c|}{ Control } \\
\cline { 2 - 5 } & Pretest & Posttest & Pretest & Posttest \\
\hline Amount & 1120,00 & 2975,00 & 960,00 & 2430,00 \\
\hline Lowest & 15,00 & 55,00 & 0,00 & 50,00 \\
\hline Highest & 55,00 & 100,00 & 50,00 & 100,00 \\
\hline Average & 31,11 & 82,64 & 30,00 & 75,94 \\
\hline
\end{tabular}

Table 3 is a data analysis of critical thinking ability assessment result. Assessment of critical thinking ability is done twice, i.e., before learning (pretest) and after learning (posttest) using two different learning media. Experiment class gets the lowest pretests value 15.00 and the highest 55.00 of the total amount of 1120.00 . Then get better results significantly on posttest with the lowest value of 55.00 and the highest 100.00 with a total amount of 2975.00. The average pretests and posttest of experiment class is 31.11 and 82.64 with a difference of 
51.53. This suggests that students' critical thinking capabilities in experiment class have increased more than $50 \%$. While the control class gets the lowest pretests value
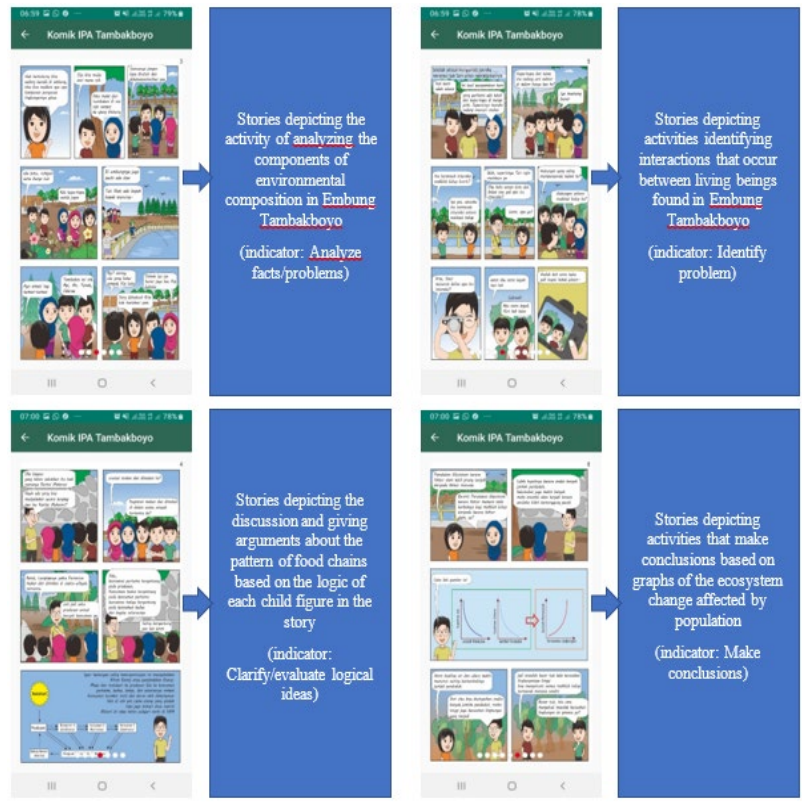

Figure 1 A few pieces of story that apply critical thinking ability in Android comics

The average pretests and posttest of control class is 30,00 and 75,94 with a difference of 45,94 . This suggests that students' critical thinking capabilities in control class have increased less than $50 \%$. These results show that the experiment class that have learned by using Android comics based on local potentials of Embung Tambakboyo has a slightly higher critical thinking ability than the control class. This statement is supported by previous research which says that by using cartoon concepts can be more effective at developing students' critical thinking ability. The colorful cartoons attract attention and can encourage students' active participation in learning activities (think more actively) thus indirectly playing an important role in helping develop critical thinking ability [5], [16], [17]. To make it clearer to see how much increased of critical thinking ability in each class, the gain value from pretests and posttest results is analyzed. The analysis results of the increased gain value of both classes can be seen in table 4 .

Table 4. Data analysis of the increased gain value.

\begin{tabular}{|l|c|c|}
\hline \multirow{2}{*}{} & \multicolumn{2}{|c|}{ Class } \\
\cline { 2 - 3 } & Experiment & Control \\
\hline Lowest & 0,43 & 0,25 \\
\hline Highest & 1,00 & 1,00 \\
\hline Average & 0,75 & 0,67 \\
\hline Category & High & Middle \\
\hline
\end{tabular}

Increasing students gain value data for the experiment class has the lowest and highest yield of 0.43 and 1.00. The average gain of 0.75 which is including into high category. As for the control class get the lowest and
0.00 and the highest 50.00 of the total amount of 960.00 . Then get posttest result with the lowest value of 50.00 and the highest 100.00 with a total amount of 2430.00 .

highest yield of 0.25 and 1.00 , with the average gain of 0.67 belonging to the middle category. Thus, it can be concluded that the Android comics based on local potentials of Embung Tambakboyo have been created and tested can improve students' critical thinking ability. Improved test results of the critical thinking ability on experiment and control class can be seen in figure 2 .

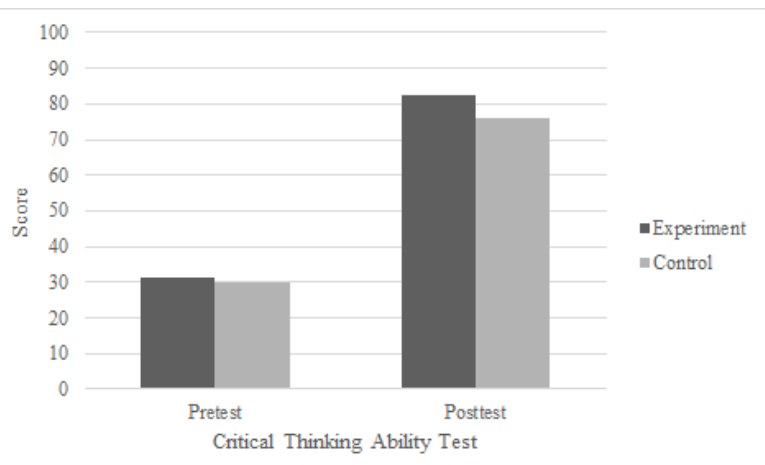

Figure 2 Graph results of pretest posttest critical thinking ability.

Figure 2 shows the average of increased value critical thinking ability in each class based on pretest and posttest results. The critical thinking ability of experiment class before and after using Android comics shows a more significant improvement over the control class who used conventional media. This is supported by the statement that the humor that is found in the comics can improve the pleasure of reading science and also contributes to students' concept understanding [18], [24]. The excess of an Android comics based on local potentials of Embung Tambakboyo in presenting material of interactions living creatures with its environment very helpful for students to understanding concepts because the stories very near with students' daily life. The concepts of material of interactions living creatures with its environment can be conveyed well using Android comics based on local potentials of Embung Tambakboyo to students. Language with simple words that fits the student's age and the presentation of the material with an attractive appearance makes students understand the concepts of science easily. In line with previous research that learning media in the form of science comics can make communication between learning components more effective in a fun way, and become intermediaries also facilitate the delivery of learning materials [14], [18], [25]. Science comics can also develop and improve students' critical thinking ability [22], [25]. Android comics based on local potentials of Embung Tambakboyo can be used as a learning facility that can convey knowledge with fun and simplify students to understand the concept that is being studied because it is contextual, has a simple and interesting look, and close 
to students' daily life. In addition, it is also effective to improve students' critical thinking ability significantly.

\section{CONCLUSION}

Android comics based on local potentials of Embung Tambakboyo can be used as an alternative learning media to improve students' critical thinking ability. The $\mathrm{N}$-gain for experiment class that learned by using the Android comics showed an increase with $\mathrm{N}$-gain classified into high category, while the control class that learned by using conventional learning media showed an increase with $\mathrm{N}$ gain in middle category. Thus, it can be concluded that the Android comics based on the local potentials of Embung Tambakboyo that has been developed can improve the critical thinking ability in science learning better than the learning media that is commonly used in schools.

\section{ACKNOWLEDGMENTS}

Researcher are very thankful to Universitas Negeri Yogyakarta, SMP Negeri 2 Depok, Sleman and various parties involved so that researchers can complete the research and write this article. Hopefully it can be useful for readers and other researchers in the same field.

\section{REFERENCES}

[1] A. A. Shahroom, N. Hussin, Industrial revolution 4.0 and education, in: International Journal of Academic Research in Bussines \& Sosial Science, 2018, p. 315 . DOI: http://dx.doi.org/10.6007/IJARBSS/v8-i9/4593

[2] A. A. Hussin, Education 4.0 made simple: ideas for teaching, in: International Journal of Education \& Literacy Studies, 2018, p. 92. DOI: http://doi.org/10.7575/aiac.ijels.v.6n.3p.92

[3] C. P. Lim, Y. Zhao, J. Tondeur, C. S. Chai, C-C. Tsai, Bridging the gap: technology trends and use of technology in schools, in: Educational Technology \& Society, 2013, p. 59.

[4] Iswan, B. Herwina, Penguatan pendidikan karakter perspektif islam dalam era millenial IR. 4.0, in: Proceeding Seminar Nasional Pendidikan Era Revolusi, 2018, p. 23.

[5] F. Demirci, C. Ozyurek, The effects of using concept cartoons in astronomy subjects on critical thinking skills among seventh grade student, in: International Electronic Journal of Elementary Education, 2017, p. 251. DOI: https://doi.org/10.26822/iejee.2017236119

[6] T. Thomas, Developing first year students' critical thinking skills, in: Asian Social Science, 2017, p. 27. DOI: http://dx.doi.org/10.5539/ass.v7n4p26
[7] J. Kleinig, Trust and critical thinking, in: Educational Philosophy and Theory, 2018, p. 135. DOI: http://doi.org/10.1080/00131857.2016.1144167

[8] R. Khisfe, Relationship between nature of science understandings and argumentation skills: a role for counterargument and contextual factors, in: Journal of Research in Science Teaching, 2012, p. 499. DOI: https://doi.org/10.1002/tea.21012

[9] S. J. Rahayu, P. Karyanto, Analysis of junior high school students' critical thinking skills profile in Surakarta, in: Proceeding International Seminar on Science Education, IOP Publishing, Bristol, 2019, p 2. DOI: http://dx.doi.org/10.1088/17426596/1233/1/012076

[10] Undang-Undang Republik Indonesia Nomor 20 tahun 2003 tentang Sistem Pendidikan Nasional pada Bab 1 Pasal 1 Ayat 16.

[11] M. P. E. Morales, Influence of culture and language sensitive physics on science attitude enhancement, in: Cultural Studies of Science Education, 2015, p. 962. DOI: https://doi.org/10.1007/s11422-0159669-5

[12] A. E. Damayanti, H. Kuswanto, The use of androidassisted comics to enhance students' critical thinking skill, in: Proceeding International Seminar on Science Education, IOP Publishing, Bristol, 2020, p. 1. DOI: https://doi.org/10.1088/17426596/1440/1/012039

[13] A. Arroio, Comics as a narrative in natural science education, in: Western Anatolia Journal of Educational Science, 2011, p. 94.

[14] J. Hosler, K. B. Boomer, Are comic books an effectiveway to engage nonmajors in learning and appreciating science? in: CBE Life Sciences Education, 2011, p. 315. DOI: https://doi.org/10.1187/cbe.10-07-0090

[15] F. Haroky, S. Nikmah, I. Wilujeng, Jumadi, H. Kuswanto, Android-assisted physics comic learning to train students' conceptual understanding of newton's gravity, in: Proceeding International Seminar on Science Education, IOP Publishing, Bristol, 2019, p. 7 . DOI: http://dx.doi.org/10.1088/17426596/1233/1/012045

[16] G. Rota, J. Izquierdo, "Comics" as a tool for teaching biotechnology in primary schools, in: Electronic Journal of Biotechnology, 2003, p. 12. DOI: https://doi.org/10.2225/vol6-issue2-fulltext10 
[17] D. I. Lestari, A. K. Projosantoso, Pengembangan media komik IPA model PBL untuk meningkatkan kemampuan berfikir analitis dan sikap ilmiah, in: Jurnal Inovasi Pendidikan IPA, 2016, p. 147. DOI: https://doi.org/10.21831/jipi.v2i2.7280

[18] M. Tatalovic, Science comics as tools for science education and communication: A brief, exploratory study, in: Journal of Science Communication, 2009, p. 2.

[19] N. Liliarti, H. Kuswanto, Improving the competence of diagrammatic and argumentative representation in physics through android-based mobile learning application, in: International Journal of Instruction, 2018, p. 108 . DOI: https://doi.org/10.12973/iji.2018.1138a

[20] R. Anesia, B. S. Anggoro, I. Gunawan, Pengembangan media komik berbasis android pada pokok bahasan gerak lurus, in: Indonesian Journal of Science and Mathematics Education, 2018, p. 56. DOI: https://doi.org/10.24042/ijsme.v1i2.2774

[21] W. S. Hadi, P. Dwijananti, Pengembangan komik fisika berbasis android sebagai suplemen pokok bahasan radioaktivitas untuk sekolah menengah atas, in: Unnes Physics Education Journal, 2015, p. 16. DOI: https://doi.org/10.15294/upej.v4i2.7431

[22] V. D. W. Aryanto, Using digital comics to enhance eLearning on anti-corruption education, in: International Journal of The Computer, The Internet and Management, 2007, p. 3.

[23] R. R. Hake, Interactive-engagement versus traditional methods: A six-thousand-student survey of mechanics test data for introductory physics courses, in: American Journal of Physics, AIP Publishing LLC, 1998, p. 65. DOI: http://doi.org/10.1119/1.18809

[24] E. Özdemir, Humor in elementary science: development and evaluation of comic strips about sound, in: International Electronic Journal of Elementary Education, 2017, pp. 842-843. DOI: https://www.iejee.com/index.php/IEJEE/article/vie $\mathrm{w} / 288$

[25] F. Fatimah, A. Widiyatmoko, Pengembangan science comic berbasis problem-based learning sebagai media pembelajaran pada tema bunyi dan pendengaran untuk siswa SMP, in: Jurnal Pendidikan IPA Indonesia, 2014, p. 146. DOI: https://doi.org/10.15294/jpii.v3i2.3114 